\title{
Temporal changes of an alfalfa succession and related soil physical properties on the Loess Plateau, China
}

\author{
Dong Li She(1), Ming An Shao(1), Luis Carlos Timm(2) and Klaus Reichardt( ${ }^{(3)}$
}

\begin{abstract}
(1) State Key Laboratory of Soil Erosion and Dryland Farming on the Loess Plateau, Research Center of Soil and Water Conservation and Ecological Environment, Chinese Academy of Sciences \& Ministry of Education, Institute of Soil and Water Conservation, Northwest A\&F University, Yangling, 712100, China; Graduate School of CAS, Beijing, 100039, China. E-mail: shedongli@gmail.com, mashao@ms.iswc.ac.cn (2)Universidade Federal de Pelotas, Faculdade de Agronomia, Departamento de Engenharia Rural, Caixa Postal 354, CEP 96001-970 Pelotas, RS, Brazil. E-mail: Icartimm@yahoo.com.br ${ }^{(3)}$ Universidade de São Paulo, Centro de Energia Nuclear na Agricultura, Laboratório de Física do Solo, Caixa Postal 96, CEP 13418-900 Piracicaba, SP, Brazil. E-mail: klaus@cena.usp.br
\end{abstract}

\begin{abstract}
The objective of this work was to investigate the relationship between changes in the plant community and changes in soil physical properties and water availability, during a succession from alfalfa (Medicago sativa L.) to natural vegetation on the Loess Plateau, China. Data from a succession sere spanning 32 years were collated, and vegetative indexes were compared to changes related to soil bulk density and soil water storage. The alfalfa yield increased for approximately 7 years, then it declined and the alfalfa was replaced by a natural community dominated by Stipa bungeana that began to thrive about 10 years after alfalfa seeding. Soil bulk density increased over time, but the deterioration of the alfalfa was mainly ascribed to a severe reduction in soil water storage, which was lowest around the time when degradation commenced. The results indicated that water consumption by alfalfa could be reduced by reducing plant density. The analysis of the data also suggested that soil water recharge could be facilitated by rotating the alfalfa with other crops, natural vegetation, or bare soil.

Index terms: Medicago sativa, agropastoral transition zone, community characteristics, soil physical properties, soil water restoration.

\section{Variações temporais de uma sucessão de alfafa e de propriedades físicas do solo a elas relacionadas no Loess Plateau, China}

\begin{abstract}
Resumo - O objetivo deste trabalho foi investigar a relação entre variações em uma comunidade de plantas e variações nas propriedades físicas do solo e na disponibilidade de água, durante uma sucessão de alfafa (Medicago sativa L.) por vegetação natural, no Platô Loess, na China. Dados de uma sucessão de 32 anos foram examinados e índices vegetativos foram comparados em relação às variações de densidade do solo e do armazenamento de água no solo. A produção de alfafa aumentou aproximadamente por sete anos, e então decresceu, e a alfafa foi substituída por uma comunidade natural dominada pela Stipa bungeana, que começou a crescer vigorosamente dez anos após a semeadura da alfafa. A densidade do solo aumentou com o tempo, e a deterioração da alfafa se deu principalmente em razão da redução severa da água armazenada no solo, que atingiu o mínimo quando a degradação da alfafa começou. Os resultados indicam que o consumo de água pela alfafa poderia ser reduzido pela redução na densidade de plantas e que a recarga de água no solo poderia ser facilitada pela rotação entre a alfafa e outras culturas, vegetação natural ou solo nu.
\end{abstract}

Termos para indexação: Medicago sativa, zona de transição agropastoril, comunidades características, propriedades físicas do solo, recuperação da água no solo.

\section{Introduction}

Restoring vegetation cover is the principal means for soil erosion control and ecosystem recovery on the Loess Plateau of China (Wang, 2002). Development of artificial grassland accelerates the process of ecosystem restoration and promotes the area's livestock industry. However, excessive use of nonnative vegetation also aggravates soil water deficits, adversely affecting sustainable growth and succession of vegetation (Li, 1983; Wang \& Zhang,
2003). Studying such successions is important for the improvement of revegetation practices.

Alfalfa (Medicago sativa L.) has been widely used in ecosystem restoration, because it grows rapidly, protects the soil surface, and adds $\mathrm{N}$ to the soil, so that it now covers over 1 million ha of farmland in China (Li et al., 2007). However, unmanaged alfalfa production has been found to be unsustainable in this region. Zhang \& Chen (1997) reported that alfalfa yields tended to initially increase, but then declined after 7 years. Field 
investigation in this transitional region revealed that the alfalfa grassland degraded quickly, and the alfalfa usable life period for livestock was very short, often spanning only 6-8 years. Alfalfa is a summer-active species with deep roots, which enable it to extract water deep within the soil profile and to maintain high transpiration rates. High water consumption by alfalfa frequently exceeds local precipitation during the growing season (Crawford \& Macfarlane, 1995; Li \& Huang, 2008). Li (1983) observed that relatively dry soil layers had formed at 2 to $10 \mathrm{~m}$ depth after six years of alfalfa growth, causing water stress to the plant. Li \& Huang (2008) showed that alfalfa yields decreased with time, after annual yield increases of $0.629 \mathrm{Mg} \mathrm{ha}^{-1}$ per year for 8 years, while soil water storage in the upper $5 \mathrm{~m}$ decreased by $33.5 \mathrm{~mm}$ per year. Li et al. (2006) attributed alfalfa degradation to species competition and excessive water consumption. Regional soil water deficits need to be replenished by rainfall. Soil physical properties, such as soil bulk density, soil porosity, and soil hydraulic conductivity, affect the process of water recharge (Li \& Shao, 2006). However, little is known about long-term changes in soil physical properties and interactions between soil physical properties and vegetation succession on the Loess Plateau.

The objective of this work was to investigate the relationship between changes in the plant community and changes in soil physical properties and water availability, during a succession from alfalfa to natural vegetation on the Loess Plateau, China.

\section{Materials and Methods}

Two experiments were carried out in the Liudaogou watershed located in Shenmu county, Shannxi province, China $\left(38^{\circ} 46^{\prime}-38^{\circ} 51^{\prime} \mathrm{N}, 110^{\circ} 21^{\prime}-110^{\circ} 23^{\prime} \mathrm{E}\right)$, which is a typical agropastoral transition zone of the Loess Plateau. The climate is semi-arid temperate, with an annual mean precipitation of $430 \mathrm{~mm}$. The mean annual pan evaporation is $785 \mathrm{~mm}$. The predominant soil type, a Los-Orthic Entisol in the Chinese Taxonomic System (Gong, 1999) or a Calcaric Regosol in the FAO Taxonomic System (FAO: Unesco, 1988), has developed a sand loam over wind-accumulated loess parent material. Further details about this area can be found in $\mathrm{Hu}$ et al. (2008).

In the first experiment, an existing succession sere, i.e., a series of stages of a particular plant succession, was selected in a relatively homogeneous field [i.e., with similar bedrock, parent material, aspect (SW), and slope $\left.\left(6^{\circ}-7^{\circ}\right)\right]$, where alfalfa had been grown in a randomized plot design for periods ranging from 4 to 32 years. Five succession stages $(4,7,10,15$, and 32-years), each established in two slope locations, had been grown in $200 \mathrm{~m}^{2}$ plots. Millet, beans, and potatoes had been grown in rotation before seeding with alfalfa, which was planted without fertilization or any subsequent management.

Vegetation surveys were conducted during the growing season (July to August, 2007). A subplot $10 \times 10 \mathrm{~m}$, within each plot, was used to characterize the vegetation. Three quadrants $(1 \times 1 \mathrm{~m}$ each $)$, positioned randomly, were surveyed within each subplot yielding data from a total of six replicates for each succession stage. The plants were separated and counted.

The plant canopy coverage (C) of each species, determined by visual estimation, was expressed as a plant cover percentage. Plant height $(\mathrm{H})$ was determined using a ruler. The above-ground biomass (dry matter) (W) was determined gravimetrically by oven-drying at $105^{\circ} \mathrm{C}$ for 1 hour and then at $70^{\circ} \mathrm{C}$ for a minimum of 72 hours. The relative canopy coverage $\left(\mathrm{C}^{\prime}\right)$, relative plant height $\left(\mathrm{H}^{\prime}\right)$, and the relative frequency $\left(\mathrm{F}^{\prime}\right)$ for a particular plant species were calculated as a ratio of these properties of each plant species. The species importance value (IV), species richness (Margalef index - M), species diversity [(Simpson index $-\mathrm{D})$ and (Shannon-Wiener index $-\mathrm{W})$ ], and species evenness [(Pielou evenness index $-J$ ) and Alatalo index - E)] were determined through the following formulas (Li \& Shao, 2005; Huang et al., 2007):

$\mathrm{IV}=\mathrm{C}^{\prime}+\mathrm{h}^{\prime}+\mathrm{F}^{\prime}$

$\mathrm{M}=(\mathrm{s}-1) / \ln \mathrm{N}$

$\mathrm{D}=1-\sum_{\mathrm{i}=1}^{\mathrm{S}} \mathrm{p}_{\mathrm{i}} \ln \left(\mathrm{p}_{\mathrm{i}}\right)$

$\mathrm{W}=-\sum_{\mathrm{i}=1}^{\mathrm{S}} \mathrm{p}_{\mathrm{i}} \ln \left(\mathrm{p}_{\mathrm{i}}\right)$

$J=\left[-\sum_{\mathrm{i}=1}^{\mathrm{S}} \mathrm{p}_{\mathrm{i}} \ln \left(\mathrm{p}_{\mathrm{i}}\right)\right] / \ln \mathrm{S}$

$E=\left[\left(\sum_{i=1}^{S} p_{i}^{2}\right)^{-1}-1\right] /\left[\operatorname{Exp}\left(-\sum_{i=1}^{S} p_{i} \ln \left(p_{i}\right)\right)-1\right]$

$\mathrm{Pi}=\mathrm{Ni} / \mathrm{N}$

in which: $\mathrm{S}$ is the number of species; $\mathrm{N}_{\mathrm{i}}$ is the number of individual species $\mathrm{i}$; and $\mathrm{N}$ is the total number of individuals for all the species. 
Soil water was determined gravimetrically at 20-day intervals throughout April to October, 2007, for each $10 \mathrm{~cm}$ increment of soil depth down to a $1.2 \mathrm{~m}$ depth (3 replicates) at points adjacent to the vegetation investigation quadrants, in each sampling subplot. At the end of the study, undisturbed soil cores were removed in steel cylinders, $50 \mathrm{~mm}$ length and $50 \mathrm{~mm}$ in diameter, from the surface $(0-20 \mathrm{~cm})$ and subsurface (20-40 cm) layers from each subplot (3 replicates each). Soil saturated hydraulic conductivity $\left(\mathrm{K}_{\mathrm{s}}\right)$ was determined by the constant hydraulic head method ( $\mathrm{Li}$ $\&$ Shao, 2006), and soil bulk density was determined after oven-drying the cores at $105-110^{\circ} \mathrm{C}$ for 24 hours following $\mathrm{K}_{\mathrm{s}}$ measurements. Soil total porosity was calculated using Equation (8):

$\mathrm{Pt}=(1-\mathrm{Bd} / \mathrm{ds}) \times 100$

in which: $\mathrm{P}_{\mathrm{t}}$ is the soil total porosity $(\%)$; $\mathrm{B}_{\mathrm{d}}$ is the soil bulk density $\left(\mathrm{g} \mathrm{cm}^{-3}\right)$; and $\mathrm{d}_{\mathrm{s}}$ is the soil particle density (taken as $2.65 \mathrm{~g} \mathrm{~cm}^{-3}$ ).

In the second experiment, soil water restoration was evaluated for dry soil layers. The soil layers had developed during alfalfa production and had been modified under different subsequent land uses.

In April 2004, three experimental plots (4x15 m) were randomly selected for alfalfa at various growth stages on hill slopes having soil similar to and in the same vicinity as those of the first experiment. In two plots alfalfa was planted in 1995 on a $13^{\circ}$ slope with a SE aspect. In one plot, alfalfa was removed in April, 2004, followed by annual plowing, while in the other plot, alfalfa was left undisturbed. In the third plot, alfalfa had been planted in 1975 on a $14^{\circ}$ slope with a SW aspect. A fourth plot was established as a control on a $12.5^{\circ}$ slope, with a SW aspect, under rainfed crops grown in a millet-potato-bean rotation. Three neutron probe (CNC500) access tubes were installed in each plot, at randomly selected locations to a depth of $4 \mathrm{~m}$, and soil moisture was measured monthly, from April to October, from 2004 to 2007. Moisture measurements were made in increments of $10 \mathrm{~cm}$, for the upper $1 \mathrm{~m}$ soil layer, and of $20 \mathrm{~cm}$ between 1 and $4 \mathrm{~m}$. Following standard procedures (McCulloch \& Wall, 1976; Li \& Huang, 2008), we derived the following calibration equation $\left(\mathrm{R}^{2}=0.98\right)$ for use in the present study:

$\theta=35.403 \times \mathrm{CR}+1.2834$

in which: $\theta$ is the gravimetrical soil moisture content (\%); and CR is the count ratio of the neutron probe.

This paper considered only data collected in 2007. Since alfalfa stands often deteriorate after 12 years of growth, we defined the vegetation succession in alfalfa older than this as natural vegetation restoration. The four plot treatments were described as follow: 12 years alfalfa field; 3 years plowed alfalfa field, after 9 years of alfalfa cropping; 20 years natural vegetation restoration field, after alfalfa cropping; and continuous cropland.

Analysis of variance (ANOVA) and correlation analysis were carried out using SPSS 11.0 procedures for sites at different succession stages. Multiple comparisons among different succession stages and different treatments were made using the Fisher least significant difference (LSD) method for a significance level, $\alpha=0.05$.

\section{Results and Discussion}

Species composition in the succession sere of the first experiment changed significantly over time (Table 1). The IV of alfalfa, the predominant species for 7 years, declined steadily over time after seeding. In contrast, the IV of Stipa bungeana increased over time, especially after the $10^{\text {th }}$ year, in which it became the predominant species. Changes also occurred among the companion species; for example, the preponderance of Artemisia capillaris decreased steadily, whereas Lespedeza daurica gradually became the main companion species, while Astragalus melilotoides maintained a constant presence. Between 15 and 32 years, the only change of significance was the emergence of some drought tolerant species (e.g., Poa sphondylodes). The plant community succession can be divided into three stages: artificial alfalfa community (1-7 years), transitional community from alfalfa to Stipa bungeana (7-15 years), and secondary natural

Table 1. Important value of the top-six dominant plant species for different growth years of alfalfa grassland.

\begin{tabular}{lccccc}
\hline Species & 4-year & 7 -year & 10 -year & 15-year & 32-year \\
\hline Medicago sativa & 201.2 & 178.2 & 60.4 & 52.4 & 43.1 \\
Artemisia capillaris & 55.8 & 35.8 & 33.1 & 27.9 & \\
Astragalus melilotoides & 22.4 & 30.4 & 12.3 & 24.7 & 21.0 \\
Ixeris chinensis & 15.4 & - & - & - & - \\
Lactuca tatarica & 14.3 & - & - & - & - \\
Salsola collina & 9.2 & - & - & - & - \\
Stipa bungeana & - & - & 72.1 & 151.8 & 160.0 \\
Astragalus adsurgens & - & 28.6 & - & - & - \\
Scorzonera muriculata & - & 18.2 & - & - & - \\
Lespedeza daurica & - & - & 12.4 & 30.2 & 33.5 \\
Polygala tenuifolia & - & - & - & 17.0 & 21.8 \\
Cleistogenes chinensis & - & - & 9.8 & - & - \\
Heteropappus altaicus & - & 11.4 & - & - & - \\
Poa sphondylodes & - & - & - & - & 29.9 \\
\hline
\end{tabular}


grassland community dominated by $S$. bungeana (15-32 years). Therefore, only 10 to 15 years were needed for the Medicago sativa stand to be succeeded by a stable $S$. bungeana prairie community. This was different from the process of natural plant restoration, which often requires a much longer period to establish a stable climax community (Li \& Shao, 2006). Planting of $M$. sativa significantly hasten the succession process toward natural vegetation at this time.

Species replacement during succession was also reflected in the changes in biomass (Figure 1). Alfalfa yields declined after about 7 years, while those of $S$. bungeana began to increase about 10 years after alfalfa seeding. The plant community biomass was at a minimum value 10 years after alfalfa seeding, but then increased with the increase in S. bungeana, which comprised the main part of the community yield at 15 and 32 years. S. bungeana was able to exploit the niche created by the decline in alfalfa predominance.

During the alfalfa succession sere, there were significant changes in the plant species diversity, species richness and species evenness (Table 2). Competition and the diversity of the community increased as the unstable alfalfa monoculture was invaded by highly competitive native species. Species richness (Margalef index), species diversity (Simpson index and Shannon-Wiener index), and species evenness (Pielou evenness index and Alatalo index) increased to maximum levels in the 7 years after alfalfa seeding stage. Competition for limited resources may have accelerated alfalfa deterioration, while native species may have benefited from increased levels of nitrogen fixed by the alfalfa plants. Following acute competition in the 7-15 years period, several species disappeared, and species richness and species evenness significantly

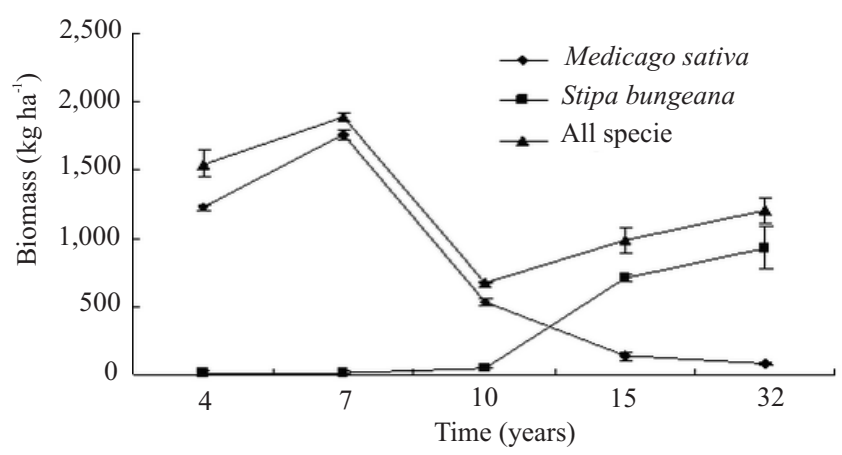

Figure 1. Biomass yield (mean \pm standard error) for plant species, as a function of time since alfalfa ( $M$. sativa) seeding. declined, along with a drop in species diversity and an increase in the concentration of few predominant species (Tables 1 and 2). The plant community had more stability 15 years following alfalfa seeding, comprising species adapted to the local conditions and the limited resources, and thus little change in the species composition in the community subsequently occurred (Table 1). All vegetative indexes followed similar trends with a characteristic single-peak curve that was related to the various stages of succession.

Significant changes in the physical properties of the soil profile occurred (Table 3 ). The bulk density of the 0-20 cm soil layer increased with the age of plantation and corresponded to related decreases in total porosity. Saturated soil hydraulic conductivity, a parameter which integrates several physical characteristics including bulk density, porosity, soil particle composition and soil hardness, significantly decreased over time in the upper $40 \mathrm{~cm}$ soil layer (Table 3 ). The bulk density of the upper $20 \mathrm{~cm}$ soil layer was significantly correlated with the majority of vegetation characteristics; however, this does not necessarily indicate a causal relationship between soil properties and vegetative succession. Some compaction may be due to plant root development and to the drying of the soil caused

Table 2. Vegetation traits of an alfalfa sere during five succession stages $^{(1)}$.

\begin{tabular}{rlcccc}
\hline $\begin{array}{c}\text { Years } \\
\text { index }\end{array}$ & $\begin{array}{c}\text { Margalef } \\
\text { index }\end{array}$ & $\begin{array}{c}\text { Shannon- } \\
\text { Wiener index }\end{array}$ & $\begin{array}{c}\text { Pielou } \\
\text { evenness index }\end{array}$ & $\begin{array}{c}\text { Alatalo } \\
\text { index }\end{array}$ \\
\hline 4 & $0.84 \mathrm{~b}$ & $0.47 \mathrm{ab}$ & $0.92 \mathrm{ab}$ & $0.63 \mathrm{ab}$ & $0.65 \mathrm{ab}$ \\
7 & $1.40 \mathrm{a}$ & $0.60 \mathrm{a}$ & $1.13 \mathrm{a}$ & $0.78 \mathrm{a}$ & $0.73 \mathrm{a}$ \\
10 & $0.82 \mathrm{~b}$ & $0.45 \mathrm{ab}$ & $1.00 \mathrm{ab}$ & $0.48 \mathrm{bc}$ & $0.47 \mathrm{c}$ \\
15 & $0.93 \mathrm{~b}$ & $0.41 \mathrm{ab}$ & $0.79 \mathrm{ab}$ & $0.49 \mathrm{bc}$ & $0.59 \mathrm{~b}$ \\
32 & $0.73 \mathrm{~b}$ & $0.37 \mathrm{~b}$ & $0.69 \mathrm{~b}$ & $0.46 \mathrm{c}$ & $0.60 \mathrm{~b}$ \\
\hline
\end{tabular}

Table 3. Soil bulk density $\left(B_{d}\right)$, soil total porosity $\left(P_{t}\right)$ and saturated soil hydraulic conductivity $\left(\mathrm{K}_{\mathrm{s}}\right)$ in alfalfa fields along a succession gradient ${ }^{(1)}$.

\begin{tabular}{rllllllll}
\hline Years & \multicolumn{2}{c}{$\mathrm{B}_{\mathrm{d}}\left(\mathrm{g} \mathrm{cm}^{-3}\right)$} & & \multicolumn{2}{c}{$\mathrm{P}_{\mathrm{t}}(\%)$} & & \multicolumn{2}{c}{$\mathrm{K}_{\mathrm{s}}\left(\mathrm{mm} \mathrm{min}^{-1}\right)$} \\
\cline { 2 - 3 } \cline { 5 - 6 } \cline { 7 - 9 } & $0-20 \mathrm{~cm}$ & $20-40 \mathrm{~cm}$ & & $0-20 \mathrm{~cm}$ & $20-40 \mathrm{~cm}$ & $0-20 \mathrm{~cm}$ & $20-40 \mathrm{~cm}$ \\
\hline 4 & $1.37 \mathrm{bc}$ & $1.42 \mathrm{~b}$ & & $48.3 \mathrm{ab}$ & $46.9 \mathrm{ab}$ & & $1.61 \mathrm{a}$ & $1.13 \mathrm{a}$ \\
7 & $1.36 \mathrm{c}$ & $1.44 \mathrm{ab}$ & & $48.8 \mathrm{a}$ & $48.7 \mathrm{a}$ & & $1.64 \mathrm{a}$ & $1.27 \mathrm{a}$ \\
10 & $1.42 \mathrm{abc}$ & $1.49 \mathrm{a}$ & & $46.3 \mathrm{abc}$ & $43.8 \mathrm{c}$ & & $1.23 \mathrm{~b}$ & $0.62 \mathrm{~b}$ \\
15 & $1.44 \mathrm{ab}$ & $1.48 \mathrm{ab}$ & & $45.8 \mathrm{bc}$ & $44.2 \mathrm{c}$ & & $0.75 \mathrm{c}$ & $0.66 \mathrm{~b}$ \\
32 & $1.46 \mathrm{a}$ & $1.46 \mathrm{ab}$ & & $44.8 \mathrm{c}$ & $45.1 \mathrm{bc}$ & & $0.75 \mathrm{c}$ & $0.61 \mathrm{~b}$ \\
\hline
\end{tabular}

(1) Means within columns, followed by the same letters, are not significantly different as determined by a Fisher least square difference test for $5 \%$ probability. 
by plant uptake of water. Increased bulk density may restrict root development, and the associated lower porosity can affect water and gas exchange, but these factors may have not significantly affected the alfalfa plants. Native plant species were able to thrive despite the higher bulk densities (Tables 1 and 3).

During the 2007 growing season, water storage in the $0-1.2 \mathrm{~m}$ soil layer varied similarly for the various succession stages and was related to the temporal pattern of rainfall events (Figure 2). Thus, the highest soil water storage amounts on September 3 followed the largest storm, which occurred from August 25 to September $1^{\text {st }}$. Likewise, the lowest soil water storage amounts were observed on July 10, following a period of low rainfall, during which the highest evapotranspiration rates were reported.

Soil moisture is often the most limiting factor affecting plant growth (Daly et al., 2004). Plant development increases water consumption and affects soil water content. The mean moisture content of the upper $1.2 \mathrm{~m}$ of soil layer was significantly and negatively correlated with above-ground biomass $(p<0.01)$, vegetation coverage $(p<0.05)$ and species evenness $(p<0.05$ and $p<0.01)$ (Table 4). Soil water storage was significantly affected by the succession stage $(p<0.05)$. During the first 7 years, alfalfa was the predominant species, and its high evapotranspiration rate and deep root system resulted in higher water consumption, reported to be at least $50 \mathrm{~mm}$ over that of other cultivated species (Crawford \& Macfarlane, 1995; Dunin et al., 2001; Li \& Huang, 2008). Thus, soil water storage was at its lowest for the first two succession stages throughout the growing season. The induced water stresses possibly accelerated the natural vegetation succession process, since the native species are drought resistant. Similar observations have been reported (Li \& Shao, 2005; Wang et al., 2007).

The transitional phase from artificial $M$. sativa grassland to natural $S$. bungeana grassland at around 10 years after sowing, when alfalfa was severely degraded but the invading native species had not yet developed, had the lowest plant community biomass (Figure 1). Lower biomass resulted in reduced soil water consumption rates so that the soil water storage was significantly increased 10 years after seeding with alfalfa $(\mathrm{p}<0.05)$ (Figure 2). In the final two succession stages, the development of the $S$. bungeana as the dominant species resulted in higher consumption and reduced soil water storage, but levels were still above those during the alfalfa dominated stages. This indicated that long-term soil moisture restoration occurred in the 0-1.2 m layer, following the decline of alfalfa.

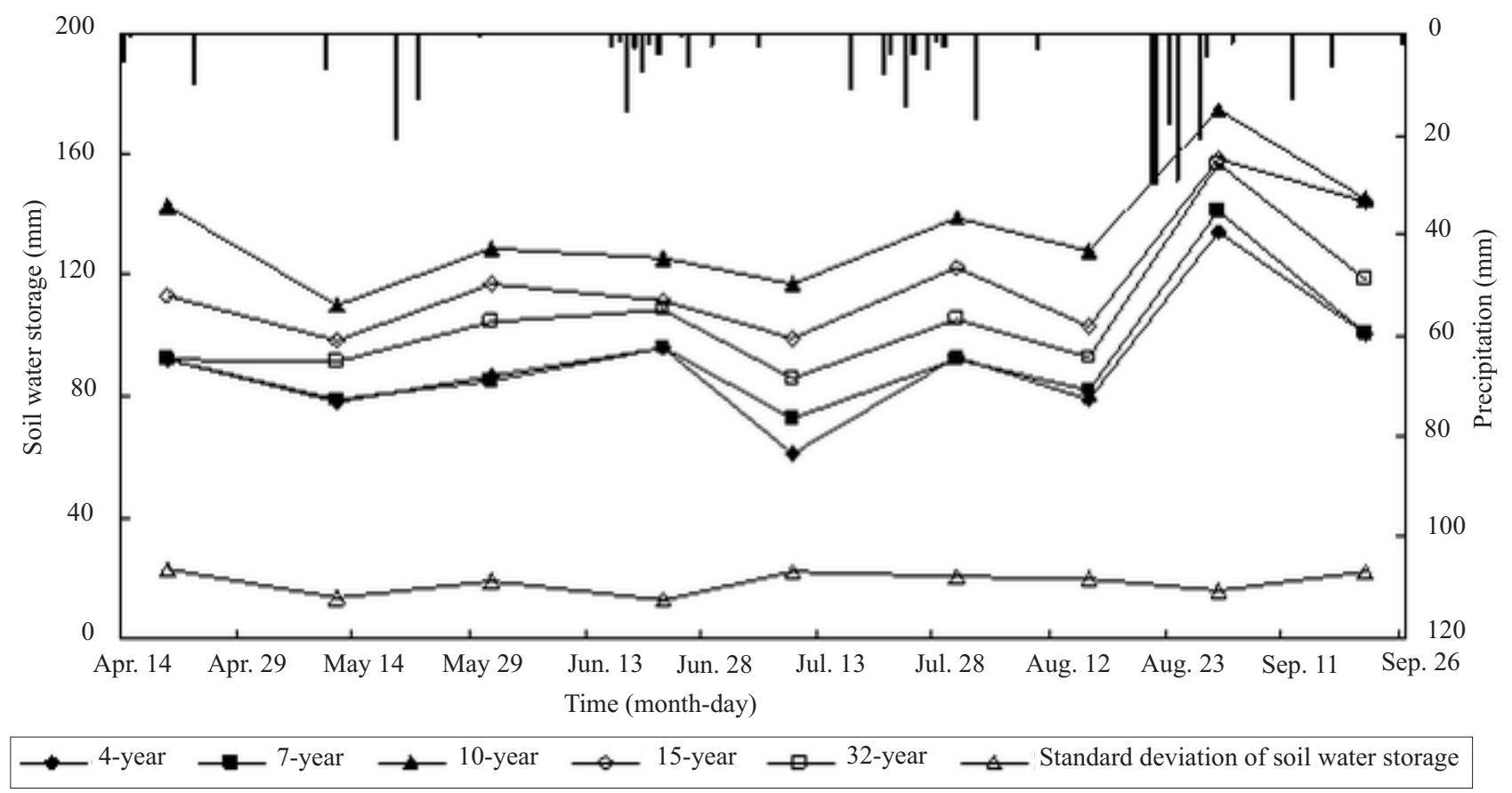

Figure 2. Water storage in the upper $120 \mathrm{~cm}$ soil layer, as a function of the time since alfalfa (M. sativa) seeding, and precipitation (-) during the 2007 growing season of alfalfa grassland. 
Moisture distribution in the upper $4 \mathrm{~m}$ soil layer in the alfalfa land and restoration land of the second experiment are presented in Figure 3. Soil water consumption was greatest in the 12-year alfalfa land $(p<0.05)$, and probably occurred even from depths below $4 \mathrm{~m}$. The mean moisture content of the 1.2-4 m soil layer was $5.80 \%$ under the continuous 12-year alfalfa treatment, very close to the wilting point of $5 \%$. Alfalfa was already severely degraded at this stage. Soil water was significantly replenished in the upper $3 \mathrm{~m}$ soil layer under restored natural vegetation where the mean moisture content of the 1.2-4 m layer was $7.29 \%$. The greatest soil water recharge occurred in the surface $3 \mathrm{~m}$, resulting in a higher mean moisture content of $7.24 \%$ for the $1.2-3 \mathrm{~m}$ soil layer under natural vegetation, than that of the corresponding depth under alfalfa $(5.41 \%)$, although this was still significantly lower than that under cropland (10.44\%).

Soil water recharge is entirely dependent on infiltrating rainwater (Li \& Huang, 2008). Soil water restoration of dried soil layers through the practice of natural vegetation restoration following alfalfa degradation is a long-term process. When alfalfa was removed and the soil plowed for 3 successive years, the maximum soil water restoration depth was $3 \mathrm{~m}$, and the mean moisture content of the 1.2-3 m soil layer was $7.43 \%$, comparable to but a little higher than that of the restored land. This implies that soil water storage levels can also be restored by land management practices ( $\mathrm{Li}$ \& Huang, 2008).

The growth and yield of alfalfa, widely planted in the agropastoral transition zone of the Loess Plateau of China, depend mainly upon ample soil water conditions and appropriate field management, without which alfalfa degrades rapidly (Hao et al., 2004). Our study showed that alfalfa could flourish in this region for about 7 years, before declining during later succession stages (Figure 1).

Competition from invading native species may also play a role in alfalfa degradation but, although species richness was at its highest level by the 7-year stage, following which alfalfa declined, these species accounted for only a small part of the plant community biomass at that stage (Figure 1). It is also possible that nutrients were limiting, but alfalfa itself is a $\mathrm{N}_{2}$ fixer. Other nutrients such as $\mathrm{K}$ and $\mathrm{P}$, which were not removed from the soil-plant system during the study by either harvesting or leaching, could possibly lead to a climax level of alfalfa rather than to alfalfa degradation.

The factor considered by others as most likely to result in alfalfa stand degradation in this region is severe consumption of soil water by alfalfa (Li \& Huang, 2008). The lowest mean moisture content measured in the $0-1.2 \mathrm{~m}$ soil layer occurred under the 7 years alfalfa growth, when the biomass was highest. During the initial years, alfalfa was able to exploit the soil water resources at depth. After about 7 years, soil moisture was close to the wilting point; and thus, we propose that alfalfa declined under water stress. Drying of the soil layers may also have led to soil hardening and increased soil physical quality degradation. Under these conditions, $S$. bungeana, a native species of the region with higher drought tolerance, was able to exploit the niche vacated by the declining alfalfa population and subsequently thrived.

Therefore, for prolonging the growth period of alfalfa, two possible field management strategies are: to control native species by tillage and weeding, thereby reducing competition for resources; and to control alfalfa plant density by intermediate cutting,

Table 4. Correlation coefficients of main vegetation characteristics and soil physical properties in vegetation succession process $^{(1)}$.

\begin{tabular}{|c|c|c|c|c|c|c|c|c|c|c|}
\hline & $\mathrm{W}$ & $\mathrm{J}$ & $\mathrm{M}$ & $\mathrm{E}$ & $\mathrm{B}$ & $\mathrm{C}$ & $\mathrm{S}$ & $\mathrm{K}_{\mathrm{s}}$ & $\mathrm{B}_{\mathrm{d}}$ & $\mathrm{P}_{\mathrm{t}}$ \\
\hline $\mathrm{D}$ & $0.962 * *$ & $0.879 * *$ & $0.800^{* *}$ & $0.633^{*}$ & $0.538^{*}$ & 0.209 & -0.221 & 0.460 & $-0.557^{*}$ & $0.557 *$ \\
\hline W & 1.000 & $0.771 * *$ & $0.714^{* *}$ & 0.408 & 0.356 & 0.000 & -0.001 & 0.447 & $-0.522 *$ & $0.522 *$ \\
\hline $\mathrm{J}$ & & 1.000 & $0.755^{* *}$ & $0.810 * *$ & $0.795 * *$ & 0.453 & $-0.530 *$ & $0.679 * *$ & $-0.713 * *$ & $0.713^{* *}$ \\
\hline M & & & 1.000 & $0.606^{*}$ & $0.674 * *$ & 0.417 & -0.301 & 0.390 & -0.414 & 0.414 \\
\hline E & & & & 1.000 & $0.832 * *$ & $0.737 * *$ & $-0.745^{* *}$ & 0.396 & -0.512 & 0.512 \\
\hline B & & & & & 1.000 & $0.679 * *$ & $-0.838 * *$ & $0.658 * *$ & $-0.620 *$ & $0.620^{*}$ \\
\hline $\mathrm{C}$ & & & & & & 1.000 & $-0.610^{*}$ & 0.083 & -0.202 & 0.202 \\
\hline $\mathrm{S}$ & & & & & & & 1.000 & -0.393 & 0.382 & -0.382 \\
\hline $\mathrm{K}_{\mathrm{s}}$ & & & & & & & & 1.000 & $-0.791 * *$ & $0.791 * *$ \\
\hline $\mathrm{B}_{\mathrm{d}}$ & & & & & & & & & 1.000 & $-1.000 * *$ \\
\hline$\underline{P_{t}}$ & & & & & & & & & & 1.000 \\
\hline
\end{tabular}

(1) D, Simpson index; W, Shannon-Wiener index; J, Pielou evenness index; M, Margalef index; E, Alatalo index; B, biomass; C, plant canopy coverage; $\mathrm{S}$, average soil moisture of the $0-120 \mathrm{~cm}$ soil layer; Ks, saturated soil hydraulic conductivity; Bd, soil bulk density; Pt, soil total porosity. * and **Significant at 5 and $1 \%$ levels (2-tailed), respectively. 
thereby reducing water consumption and avoiding water stress.

A further management strategy would be to change the land use, in order to replenish the soil water as soon as the alfalfa crop begins to degrade. Alfalfa creates a dry soil layer, with a persistent low water content, extending downwards over time as deeper soil water is exploited. A secondary succession after alfalfa degradation resulted in water recharge of the dry soil layers, but this is a slow long-term process. Furthermore, Li \& Huang (2008) indicated that on the Loess Plateau, it was impossible to entirely recharge the soil water by rainfall infiltration under these conditions. Nevertheless, transferring land use from alfalfa grassland to bare land or cropland could accelerate the water recharge, by rainfall infiltration, to levels existing prior to alfalfa introduction.

Our results also showed that soil moisture restoration, after 3 years of bare land following 9 years of continuous alfalfa growth, was similar to that of 20 years of secondary succession, markedly accelerating the soil water restoration of the dry soil

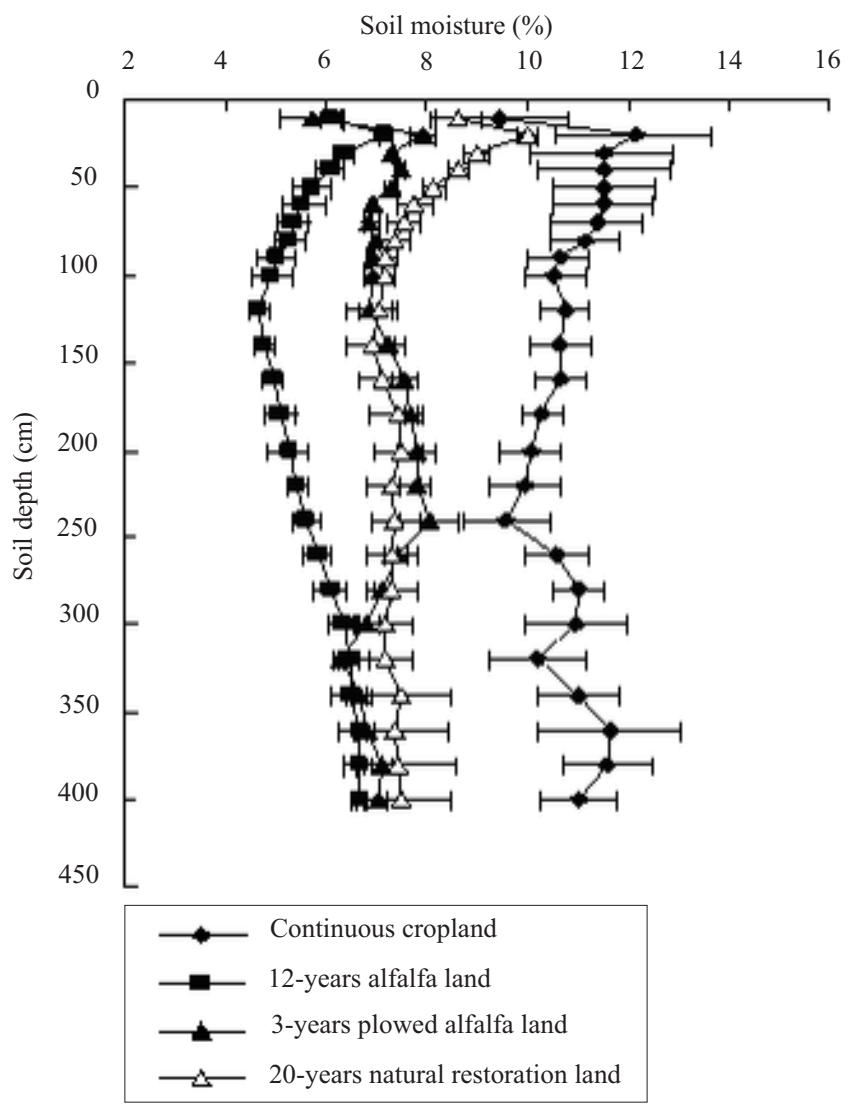

Figure 3. Distribution of soil water content with soil depth under different plant succession communities. layers. Potentially, six years of bare land would restore water levels to those under cropland, the original condition under which alfalfa could be grown for 7 years or more. However, the use of bare ground cover, possibly doing so in combination with other areas of ground having some vegetative cover, must take into account the potential soil erosion problems caused by wind or overland water flow.

\section{Conclusions}

1. Alfalfa yield increased for about 7 years after seeding then declined and alfalfa was replaced by a natural community dominated by Stipa bungeana, that began to thrive about 10 years after seeding with alfalfa.

2. Soil bulk density increases over time and soil water is severely depleted under alfalfa.

3. The decline in alfalfa yield was most likely directly related to water stress resulting from depletion of soil water at depth, rather than by competition from native species.

4. Restricting the plant density could reduce water consumption by alfalfa; while soil water recharge may be facilitated by rotating alfalfa with other crops, natural vegetation or by leaving the soil bare for more than three years before replanting.

\section{Acknowledgements}

To the National Natural Science Foundation of China and the innovation team project of Chinese Academy of Sciences, for financing this research; to Dr. David Warrington, for improving the quality of the manuscript.

\section{References}

CRAWFORD, M.C.; MACFARLANE, M.R. Lucerne reduces soil moisture and increases livestock production in an area of high groundwater recharge potential. Australian Journal of Experimental Agriculture, v.35, p.171-180, 1995.

DALY, E.; PORPORTO, A.; RODRIGUEZ-ITURBE, I. Coupled dynamics of photosynthesis, transpiration, and soil water balance: part II: stochastic analysis and ecohydrological significance. Journal of Hydrometeorology, v.5, p.559-566, 2004.

DUNIN, F.X.; SMITH, C.J.; ZEGELIN, S.J.; LEUNING, R.; DENMEAD, O.T.; POSS, R. Water balance changes in a crop rotation involving lucerne. Australian Journal of Experimental Agriculture, v.52, p.247-261, 2001.

FAO; UNESCO. Soil Map of the World. World Soil Resources Report 60. Rome: FAO, 1988. 
GONG, Z.T. Chinese soil taxonomy: theory, method, practice. Beijing: Science Press, 1999. p.23-28. (in Chinese).

HAO, M.D.; ZHANG, C.X.; WEI, X.R.; WANG, X.G.; GAO, C.Q. Effect of rotation and fertilization to alfalfa productivity on the Loess Plateau. Acta Agrestia Sinica, v.12, p.195-198, 2004. (in Chinese).

HU, W.; SHAO, M.A.; WANG, Q.J.; REICHARDT, K. Soil water content temporal-spatial variability of the surface layer of a Loess Plateau hillside in China. Scientia Agricola, v.65, p.277-289, 2008.

HUANG, D.; WANG, K.; WU, W.L. Dynamics of soil physical and chemical properties and vegetation succession characteristics during grassland desertification under sheep grazing in an agropastoral transition zone in Northern China. Journal of Arid Environments, v.70, p.120-136, 2007.

LI, X.L.; SU, D.R.; YUAN, Q.H. Ridge-furrow planting of alfalfa (Medicago sativa L.) for improved rainwater harvest in rainfed semiarid areas in Northwest China. Soil and Tillage Research, v.93, p.117-125, 2007.

LI, Y.S. The properties of water cycle in soil and their effect on water cycle for land in the Loess Plateau. Acta Ecologica Sinica, v.3, p.91-101, 1983. (in Chinese).

LI, Y.S.; HUANG, M.B. Pasture yield and soil water depletion of continuous growing alfalfa in the Loess Plateau of China. Agriculture, Ecosystems and Environment, v.124, p.24-32, 2008.

LI, Y.Y.; SHAO, M.A. Change of soil physical properties under long-term natural vegetation restoration in the Loess Plateau of China. Journal of Arid Environments, v.64, p.77-96, 2006.
LI, Y.Y.; SHAO, M.A. Degradation process and plant diversity of alfalfa grassland in North Loess Plateau of China. Chinese Journal of Applied Ecology, v.16, p.2321-2327, 2005. (in Chinese).

LI, Y.Y.; SHAO, M.A.; SHUANG, G.Z.P.; FAN, J.; WANG, L.M. Study on the degrading process and vegetation succession of Medicago sativa grassland in North Loess Plateau, China. Acta Prataculturae Sinica, v.15, p.85-92, 2006. (in Chinese).

McCULLOCH, D.B.; WALL, T. A method of measuring neutron absorption cross-sections of soil samples for calibration of the neutron moisture meter. Nuclear Instruments and Methods in Physics Research, v.137, p.557-581, 1976.

WANG, C.T.; CAO, G.M.; WANG, Q.L.; SHI, J.J.; DU, Y.G.; LONG, R.J. Characteristics of artificial grassland communities with different establishment duration and their relationships with soil properties in the source region of Three Rivers in China. Journal of Applied Ecology, v.18, p.2426-2431, 2007. (in Chinese).

WANG, G.H. Plant traits and soil chemical variables during a secondary vegetation succession in abandoned fields on the Loess Plateau. Acta Botanica Sinica, v.44, p.990-998, 2002.

WANG, G.H.; ZHANG, X.S. Supporting of potential forage production to the herbivore-based pastoral farming industry on the Loess Plateau. Acta Botanica Sinica, v.45, p.1186-1194, 2003.

ZHANG, C.E.; CHENG, X.L. Characteristics of soil enzymatic activity and nutrient of pasture from abandoned field in different years on the loess hilly areas. Acta Agronomica Sinica, v.5, p.196-200, 1997. (in Chinese).

Received on May 7, 2008 and accepted on November 28, 2008

Pesq. agropec. bras., Brasília, v.44, n.2, p.189-196, fev. 2009 